\title{
Growth, Gas Exchange, and Mineral Nutrients of Ornamental Grasses Irrigated with Saline Water
}

\author{
Yuxiang Wang \\ Western Arid Region Grassland Resources \& Ecology Key Lab, Xinjiang \\ Agricultural University, No. 311 East Nongda Road, Urumqi, Xinjiang \\ 830052, China
}

\author{
Youping Sun \\ Department of Plants, Soils, and Climate, Utah State University, 4820 Old \\ Main Hill, Logan, UT 84322
}

\section{Genhua Niu}

Department of Horticultural Sciences, Texas A\&M AgriLife Research and Extension Center, Texas A\&M University System, 17360 Coit Road, Dallas, TX 75252

\section{Chaoyi Deng, Yi Wang, and Jorge Gardea-Torresdey \\ Department of Chemistry and Biochemistry, The University of Texas at El Paso, 500 West University Avenue, El Paso, TX 79968}

Additional index words. Eragrostis spectabilis, mineral nutrient, Miscanthus sinensis, Panicum virgatum, Schizachyrium scoparium, salt tolerance

\begin{abstract}
Ornamental grasses are commonly used in urban landscapes in Utah and the Intermountain West of the United States. The relative salt tolerance of Eragrostis spectabilis (Pursh) Steud. (purple love grass), Miscanthus sinensis Andersson 'Gracillimus' (maiden grass), Panicum virgatum L. 'Northwind' (switchgrass), and Schizachyrium scoparium (Michx.) Nash (little bluestem) were evaluated in a greenhouse. Plants were irrigated with a nutrient solution at an electrical conductivity (EC) of $1.2 \mathrm{dS} \cdot \mathrm{m}^{-1}$ (control), or saline solution at an EC of 5.0 or $10.0 \mathrm{dS} \cdot \mathrm{m}^{-1}$. At harvest (65 days after the initiation of treatment), $P$. virgatum and $S$. scoparium exhibited no foliar salt damage, and $E$. spectabilis and $M$. sinensis had minimal foliar salt damage when irrigated with saline solution at an EC of $5.0 \mathrm{dS} \cdot \mathrm{m}^{-1}$. At an EC of $10.0 \mathrm{dS} \cdot \mathrm{m}^{-1}, P$. virgatum and $S$. scoparium still had no foliar salt damage, but $E$. spectabilis and $M$. sinensis displayed slight foliar salt damage, with visual scores greater than $3(0=$ dead; $5=$ excellent $)$. Compared with the control, saline solution at an EC of 5.0 and $10.0 \mathrm{dS} \cdot \mathrm{m}^{-1}$ reduced the shoot dry weight of all ornamental grasses by $25 \%$ and $46 \%$, respectively. The leaf sodium $\left(\mathrm{Na}^{+}\right)$concentration of $E$. spectabilis, $M$. sinensis, $P$. virgatum, and $S$. scoparium irrigated with saline solution at an EC of $10.0 \mathrm{dS} \cdot \mathrm{m}^{-1}$ increased 14.3, 52.6, 5.3, and 1.7 times, respectively, and the chloride $\left(\mathrm{Cl}^{-}\right)$concentration increased by 9.4, 11.1, 2.8, and 2.7 times, respectively. As a result of the salt-induced water deficit, plant height, leaf area, number of inflorescences and tillers, net photosynthesis rate $\left(P_{n}\right)$, stomatal conductance $\left(g_{S}\right)$, and transpiration rate of four tested ornamental grasses decreased to some extent. Although high $\mathrm{Na}^{+}$and $\mathrm{Cl}^{-}$accumulated in the leaf tissue, all ornamental grass species still had a good visual quality, with average visual scores greater than 3 . In conclusion, all ornamental grasses showed a very strong tolerance to the salinity levels used in this research.
\end{abstract}

Water conservation is becoming critically important throughout the United States, especially in Utah and the Intermountain West, one of the driest and fastest growing regions in the United States. The green industry in this arid to semiarid region would earnestly consider alternative water sources such as treated and reclaimed sewage effluent (reclaimed water) for water conservation and improved environmental stewardship. Reclaimed water has been a viable alternative source for landscape irrigation in Utah, with an established use record on golf courses. Reclaimed water is also used by a handful of large corporate and municipal parks and landscapes in arid and semiarid urban areas across the Desert Southwest (Grieve, 2011; Tanji et al., 2008). As Utah and the West work toward improved water conservation, the chances are good that water will be restricted until only minimums are applied. This has the potential to reduce the leaching fraction of irrigation to the point that soil salinity will gradually increase, especially in salt-prone areas using reclaimed water. It is essential to select salt-tolerant plants for landscape use in those salt-prone areas.

Reclaimed water has a relatively high salinity level and undesirable specific ions (Grieve, 2011) that could impose salt stress on a large number of landscape plants (Niu and Cabrera, 2010; Sun et al., 2015a; Wu and Dodge, 2005). Landscape plants have been evaluated for salt tolerance. Since 2005, researchers at the Texas A\&M AgriLife Research Center at El Paso have screened more than 150 landscape plant species and/or cultivars in greenhouse conditions (Niu and Cabrera, 2010; Niu et al., 2011; Sun et al., 2015a). All these studies showed consistently that the salt tolerance of landscape plants varies highly with species and/or cultivars (Chen et al., 2017; Liu et al., 2017; Sun et al., 2015a). However, limited research-based information on the salt tolerance of ornamental grasses is available.

Ornamental grasses have drawn considerable attention in the U.S. green industry as a result of their high drought tolerance, low maintenance input, and the unique textures and patterns they contribute to the landscape (Gunnell et al., 2015). Nursery production and landscape use have expanded significantly, with an estimated $\$ 158$ million worth of ornamental grasses sold annually in the United States (U.S. Department of Agriculture, 2015). Ornamental grasses are popular in urban landscapes in Utah and the Intermountain West of the United States. Eragrostis spectabilis (purple love grass) is a warm-season bunchgrass with flat, coarse green leaves and soft reddish purple flowers in a loose and open inflorescence (Missouri Botanical Garden, 2018). The inflorescence of purple love grass is good for dried flower arrangements. Miscanthus sinensis 'Gracillimus', commonly called chinese silver grass or maiden grass, is a clump-forming warm-season grass that features narrow green leaves with a silver midrib and tiny reddish copper flowers in tassel-like inflorescences (Missouri Botanical Garden, 2018). Maiden grass produces long-lasting dried flowers for winter interest. Panicum virgatum 'Northwind' (switchgrass), an introduction of Northwind Perennial Farm (Burlington, WI), is a warm-season grass with finely textured, pink-tinged, branched panicle inflorescences and olive- to bluish green foliage forming a compact, narrow, erect clump (Missouri Botanical Garden, 2018). Schizachyrium scoparium (little bluestem) is one of the dominant grasses of the tallgrass prairie region and features upright clumps of slender, flat, linear green leaves with purplish bronze flowers in racemes (Missouri Botanical Garden, 2018). These four ornamental grass species belong to the grass family (Poaceae). They tolerate a wide range of soils and drought conditions and are accent specimens for garden and urban landscapes.

The salt tolerance of a few ornamental grasses have been evaluated. In general, coolseason grasses usually have less salt tolerance than warm-season grasses (Schiavon et al., 2012, 2014). In a 4-month experiment, Leymus arenarius (L.) Hochst. (sand ryegrass), Muhlenbergia capillaris (Lam.) Trin. (pink muhly grass), and Pennisetum alopecuroides (L.) Spreng. (fountain grass) showed a very strong salt tolerance with an 
acceptable visual quality, although plant growth was inhibited by the increasing salinity (Sun and Palmer, 2018). Bouteloua gracilis (Willd. ex Kunth) Lag. ex Griffiths (blue grama) has moderate tolerance to salinity when grown at a saturated soil extract $\left(\mathrm{EC}_{\mathrm{e}}\right)$ of 4 to $8 \mathrm{dS} \cdot \mathrm{m}^{-1}$ (Kratsch et al., 2008), and its salt tolerance varies within ecotypes and is greater at the germination stage than the mature stage (Zhang et al., 2012). P. alopecuroides 'Hameln' is slightly more tolerant to salt spray than M. sinensis 'Gracillimus' (Alvarez, 2006). Pennisetum clandestinum Hochst. ex Chiov. (kikuyugrass) is a suitable candidate for the saline-sodic water reuse system with a threshold $\mathrm{EC}_{\mathrm{e}}$ of $8.0 \mathrm{dS} \cdot \mathrm{m}^{-1}$ (Grieve et al., 2004, 2012). Pink muhly grass can survive at sodium chloride $(\mathrm{NaCl})$ irrigation rates of $10,000 \mathrm{mg} \cdot \mathrm{L}^{-1}$ (corresponding to an $\mathrm{EC}$ of $\approx 12.5 \mathrm{dS} \cdot \mathrm{m}^{-1}$ ), which is up to 20 times greater than graywater (Christova-Boal et al., 1996; LeCompte et al., 2016). Because diverse ornamental grasses are produced by the green industry, further research is needed to identify salt-tolerant ornamental grasses for landscape use. This study was designed to assess the salt tolerance of four commonly used ornamental grasses in response to saline

Received for publication 7 Feb. 2019. Accepted for publication 24 Apr. 2019

This research was supported in part by the U.S. Department of Agriculture (USDA) National Institute of Food and Agriculture Hatch project UTA01381, New Faculty Start-up Funds from the Office of Research and Graduate Studies, the Center for Water-Efficient Landscaping at Utah State University. This research was also supported by the Utah Agricultural Experiment Station, Utah State University, and approved as journal paper no. 9177. We also appreciate the financial support from Grassology Peak Discipline Foundation of Xinjiang Uygur Autonomous Region and National Modern Agricultural Technology \& Industry System (CARS-34) of China to Yuxiang Wang as a visiting scholar at Utah State University, Logan, UT.

We acknowledge the National Science Foundation and the Environmental Protection Agency under Cooperative Agreement Number DBI-1266377. Also, we acknowledge the USDA grant 2016-67021-24985 and the NSF Grants EEC-1449500, CHE-0840525 and DBI-1429708. Partial funding was provided by the NSF ERC on Nanotechnology-Enabled Water Treatment (EEC-1449500). J.G.-T. acknowledges the Dudley family for the Endowed Research Professorship and also the 2018 University of Texas System's STARs Retention Award.

We are grateful for the in-kind support of plant materials from Hoffman Nursery (Rougemont, NC), chloride analyses from Christina Perez, technical assistance from Alyssa Palmer, and valuable comments from anonymous reviewers.

The content is solely the responsibility of the authors and does not necessarily represent the official views of the funding agencies. Mention of a trademark, proprietary product, or vendor does not constitute a guarantee or warranty of the product by the USDA and the American Society for Horticultural Science, and does not imply its approval to the exclusion of other products or vendors that also may be suitable.

Y.S. is the corresponding author. E-mail: youping. sun@usu.edu. solution irrigation through comparing their growth, gas exchange, and mineral nutrients.

\section{Materials and Methods}

Plant materials, treatments, and growing conditions. Ornamental grasses including $E$. spectabilis, $M$. sinensis 'Gracillimus', $P$. virgatum 'Northwind', and $S$. scoparium were used in this study. On 5 Oct. 2017, plugs $(\approx 10 \mathrm{~cm}$ tall $)$ in 32 -cell trays $(5.5 \times 5.5 \times$ $10.5 \mathrm{~cm})$ were received from Hoffman Nursery (Rougemont, NC). They were transplanted in 3.8-L, injection-molded, polypropylene pots (PC1D-4; Nursery Supplies, Orange, CA) containing a soilless growing substrate $[75 \%$ peatmoss (Canadian sphagnum peatmoss; SunGro Horticulture, Agawam, MA), 25\% vermiculite (Therm-ORock West, Chandler, AZ), and $0.8 \mathrm{~kg} \cdot \mathrm{m}^{-3}$ white athletic field-marking gypsum (92\% calcium sulfate dihydrate, $21 \%$ calcium, $17 \%$ sulfur; Western Mining and Minerals, Bakersfield, CA)]. All plants were irrigated with tap water (Table 1) as needed. Plants were kept in a greenhouse in Logan, UT (lat. $41^{\circ} 45^{\prime} 28^{\prime \prime} \mathrm{N}$, long. $111^{\circ} 48^{\prime} 47^{\prime \prime} \mathrm{W}$; elevation, $1409 \mathrm{~m}$ ) before the experiment.

On 13 Apr. 2018, all plants were pruned to $15 \mathrm{~cm}$ high and repotted into 7.6-L, injectionmolded, polypropylene containers (No. 2B, Nursery Supplies) with the same potting media described earlier. On 25 Apr., uniform plants were chosen for the experiment, and all plants were pruned again to $15 \mathrm{~cm}$ high. From 25 Apr. to 25 June, plants were irrigated roughly every $4 \mathrm{~d}$ with a nutrient solution at an EC of $1.2 \mathrm{dS} \cdot \mathrm{m}^{-1}$, or saline solution at an EC of 5.0 or $10.0 \mathrm{dS} \cdot \mathrm{m}^{-1}$ (Table 1) at $1.5 \mathrm{~L}$ per pot, resulting in a leaching fraction of $34.5 \% \pm 15.4 \%$. A nutrient solution was prepared by adding $0.8 \mathrm{~g} \cdot \mathrm{L}^{-1} 15 \mathrm{~N}-2.2 \mathrm{P}-12.5 \mathrm{~K}$ water-soluble fertilizer (Peters Excel 15-5-15 Ca-Mag Special; ICL Specialty Fertilizers, Dublin, $\mathrm{OH}$ ) to the tap water and used as the control. The saline solution was created by adding $\mathrm{NaCl}$ and calcium chloride $\left(\mathrm{CaCl}_{2}\right)$ to the nutrient solution (Table 1). $\mathrm{NaCl}$ is the common salt in reclaimed water (Niu and Cabrera, 2010), whereas $\mathrm{CaCl}_{2}$ is used to prevent potential calcium deficiencies (Carter and Grieve, 2006). The $\mathrm{pH}$ of all solutions was adjusted to $6.7 \pm 0.1$ using nitric acid $\left(\mathrm{HNO}_{3}\right)$. Both nutrient and saline solutions were prepared in 100-L tanks, with EC (Table 1) confirmed using an EC meter (LAQUA Twin; Horiba, Kyoto, Japan). Right after treatment solution was applied, leachate EC was determined using the pour-through protocol described by Cavins et al. (2008) and Wright (1986). The leachate EC, one plant per treatment per species, was measured using the EC meter and averaged across species. The substrate final ECe was determined using a saturated soil paste technique (Gavlak et al., 1994).

During the entire experiment (13 Apr.-29 June 2018), the average air temperature in the greenhouse was $26.2 \pm 1.9^{\circ} \mathrm{C}$ during the day and $19.6 \pm 5.0^{\circ} \mathrm{C}$ at night, and the average daily light integral inside the greenhouse was
$17.5 \times 3.6 \mathrm{~mol} \cdot \mathrm{m}^{-2} \cdot \mathrm{d}^{-1}$. Supplemental light at light intensities of $160 \pm 32 \mu \mathrm{mol} \cdot \mathrm{m}^{-2} \cdot \mathrm{s}^{-1}$ at the canopy level was provided using $1000-\mathrm{W}$ high-pressure sodium lamps (Hydrofarm, Petaluma, CA) from 600 to $2200 \mathrm{HR}$, when light intensity inside the greenhouse was less than $544 \mu \mathrm{mol} \cdot \mathrm{m}^{-2} \cdot \mathrm{s}^{-1}$ from $13 \mathrm{Apr}$. to $2 \mathrm{May}$.

Foliar salt damage and plant growth. A reference scale (visual score) from 0 to 5 , where $0=$ dead, $1=$ severe foliar damage $(>90 \%$ leaves with burn and necrosis at the top part of leaf blade), $2=$ moderate foliar damage $(50 \%$ to $90 \%), 3=$ slight foliar damage $(<50 \%), 4=$ good quality with minimal foliar damage, and $5=$ excellent with no foliar damage (Sun et al., 2015a) was used to rate foliar salt damage. Plant size was not considered during the evaluation of the foliar salt damage. On 29 June ( $65 \mathrm{~d}$ after the initiation of treatment), all plants were harvested as plant roots were heavily circled in 2-gal containers. Plant height (in centimeters) was recorded from the pot rim to the tip of the tallest leaf. The number of inflorescences and tillers was counted. Plant shoots were cut at the substrate surface, and leaf area was determined using an area meter (LI3100; LI-COR ${ }^{\circledR}$ Biosciences, Lincoln, NE). Shoot dry weight was determined when plant shoots were dried in an oven at $70^{\circ} \mathrm{C}$ for $3 \mathrm{~d}$.

Chlorophyll content and gas exchange. At harvest, soil-plant analysis development (SPAD) readings were taken from 10 fully expanded leaves on each plant using a handheld chlorophyll meter (SPAD 502 Plus; Minolta Camera Co., Osaka, Japan), and the average values was recorded for representing relative chlorophyll content. Fully expanded leaves at the top of at least six plants per treatment per species were measured $3 \mathrm{~d}$ before harvest for $\left(\mathrm{P}_{\mathrm{n}}\right), g_{\mathrm{S}}$, and transpiration rate using a portable photosynthesis system with an automatic universal PLC6 broadleaf cuvette (CIRAS-3; PP Systems, Amesbury, MA). Data were recorded when the environmental conditions (leaf temperature, $25{ }^{\circ} \mathrm{C}$; photosynthetic photon flux, $1000 \mu \mathrm{mol} \cdot \mathrm{m}^{-2} \cdot \mathrm{s}^{-1}$; and carbon dioxide concentration, 400 $\mu \mathrm{mol} \cdot \mathrm{mol}^{-1}$ ) and gas exchange parameters within the cuvette became stable. Gas exchange measurements were acquired on a sunny day between 1000 and $1400 \mathrm{HR}$, and plants were well watered to avoid water stress.

Mineral analyses. To analyze $\mathrm{Na}^{+}, \mathrm{Cl}^{-}$, calcium $\left(\mathrm{Ca}^{2+}\right)$, and potassium $\left(\mathrm{K}^{+}\right)$concentrations in leaves, four plants per ornamental grass species per treatment were selected randomly, and dried plant materials were ground to pass through a 40-mesh screen with a stainless Wiley mill (Thomas Scientific, Swedesboro, NJ). Powder samples were submitted to Texas A\&M AgriLife Research Center (El Paso, TX) for $\mathrm{Cl}^{-}$analyses and to the University of Texas (El Paso, TX) for macronutrient $\left[\mathrm{Ca}^{2+}, \mathrm{K}^{+}\right.$, magnesium $\left(\mathrm{Mg}^{2+}\right)$, phosphorus $(\mathrm{P})$, and sulfur $(\mathrm{S})]$ and micronutrients $\left[\mathrm{Na}^{+}\right.$, zinc $\left(\mathrm{Zn}^{2+}\right)$, iron $\left(\mathrm{Fe}^{3+}\right)$, and manganese $\left.\left(\mathrm{Mn}^{2+}\right)\right]$ analyses. The powder samples were extracted using $2 \%$ acetic acid (Fisher Scientific, Fair Lawn, NJ) following the protocol described by Gavlak et al. (1994). The $\mathrm{Cl}^{-}$concentration was determined 
Table 1. The chemical compositions of treatment solutions used in the experiment.

\begin{tabular}{|c|c|c|c|c|}
\hline \multirow[b]{2}{*}{ Item } & \multirow[b]{2}{*}{ Tap water } & \multirow{2}{*}{$\begin{array}{l}\text { Nutrient solution }{ }^{\mathrm{z}} \\
\quad \text { (control) }\end{array}$} & \multicolumn{2}{|c|}{ Saline solution $^{\mathrm{y}}$} \\
\hline & & & EC 5 & EC 10 \\
\hline $\mathrm{NaCl}\left(\mathrm{g} \cdot \mathrm{L}^{-1}\right)$ & - & - & 0.92 & 2.27 \\
\hline $\mathrm{CaCl}_{2}\left(\mathrm{~g} \cdot \mathrm{L}^{-1}\right)$ & - & - & 0.88 & 2.18 \\
\hline $\mathrm{Ca}^{2+}\left(\mathrm{mg} \cdot \mathrm{L}^{-1}\right)$ & 47.2 & 82.5 & 362.5 & 759.8 \\
\hline $\mathrm{Mg}^{2+}\left(\mathrm{mg} \cdot \mathrm{L}^{-1}\right)$ & 17.3 & 27.6 & 29.1 & 30.9 \\
\hline $\mathrm{Na}^{+}\left(\mathrm{mg} \cdot \mathrm{L}^{-1}\right)$ & 1.4 & 0.4 & 359.6 & 872.4 \\
\hline $\mathrm{SO}_{4}{ }^{2-}\left(\mathrm{mg} \cdot \mathrm{L}^{-1}\right)$ & 8.9 & 11.2 & 11.2 & 11 \\
\hline $\mathrm{Cl}^{-}\left(\mathrm{mg} \cdot \mathrm{L}^{-1}\right)$ & 3.4 & 5.7 & 1,050 & 2,780 \\
\hline $\mathrm{B}^{3+}\left(\mathrm{mg} \cdot \mathrm{L}^{-1}\right)$ & 0 & 0.23 & 0.22 & 0.2 \\
\hline Sodium adsorption ratio (SAR) & 0.04 & 0.07 & 4.88 & 8.42 \\
\hline Adjusted SAR & 0.09 & 0.13 & 11.2 & 20.9 \\
\hline $\mathrm{EC}\left(\mathrm{dS} \cdot \mathrm{m}^{-1}\right)$ & 0.37 & $1.21 \pm 0.07$ & $4.99 \pm 0.09$ & $9.89 \pm 0.27$ \\
\hline
\end{tabular}

${ }^{\mathrm{z}}$ A nutrient solution at an electrical conductivity (EC) of $1.2 \mathrm{dS} \cdot \mathrm{m}^{-1}$ (control) was prepared by adding 0.8 g. $\mathrm{L}^{-1} 15 \mathrm{~N}-2.2 \mathrm{P}-12.5 \mathrm{~K}$ water-soluble fertilizer (Peters Excel 15-5-15 Ca-Mag Special; ICL Specialty Fertilizers, Dublin, $\mathrm{OH})$ to tap water.

${ }^{\mathrm{y}}$ Saline solution at an EC of $5.0 \mathrm{dS} \cdot \mathrm{m}^{-1}$ (EC 5) or $10.0 \mathrm{dS} \cdot \mathrm{m}^{-1}$ (EC 10) was created by adding sodium chloride $(\mathrm{NaCl})$ and calcium chloride $\left(\mathrm{CaCl}_{2}\right)$ to the nutrient solution.

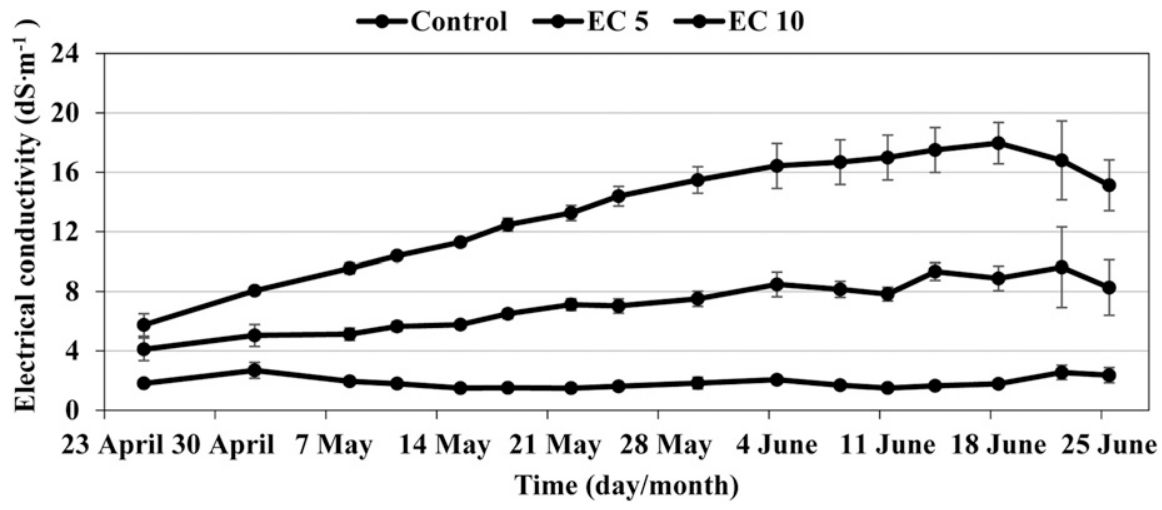

Fig. 1. Time course of the electrical conductivity (EC) of leachate solution collected after ornamental grasses were irrigated with a nutrient solution at an $\mathrm{EC}$ of $1.2 \mathrm{dS} \cdot \mathrm{m}^{-1}$ (control), or a saline solution at an EC of $5.0 \mathrm{dS} \cdot \mathrm{m}^{-1}$ (EC 5) or $10.0 \mathrm{dS} \cdot \mathrm{m}^{-1}$ (EC 10) in a greenhouse. Saline solution was created by adding sodium chloride and calcium chloride to the nutrient solution. Vertical bars represent SES of four measurements, one plant per treatment per ornamental grass species.

using a chloride analyzer (M926; Cole Parmer Instrument Company, Vernon Hills, IL) and is reported on a dry plant basis (as milligrams per gram). At the University of Texas at El Paso, powder samples $(\approx 0.2 \mathrm{~g})$ were digested in 2.5 $\mathrm{mL}$ of plasma pure $\mathrm{HNO}_{3}$ (SCP Science, Champlain, NY) that were incubated in a Digiprep hot block (SCP Science) at $115^{\circ} \mathrm{C}$ for 45 min until samples were totally dissolved. If undigested material remained, $1 \mathrm{~mL} 30 \%$ hydrogen peroxide was added and the samples were returned to incubation for additional 20 $\mathrm{min}$. The digested solutions were adjusted to 45 $\mathrm{mL}$ with millipore water. Macronutrients $\left(\mathrm{Ca}^{2+}\right.$, $\mathrm{K}^{+}, \mathrm{Mg}^{2+}, \mathrm{P}$, and $\left.\mathrm{S}\right)$ and micronutrients $\left(\mathrm{Na}^{+}\right.$, $\mathrm{Zn}^{2+}, \mathrm{Fe}^{3+}$, and $\mathrm{Mn}^{2+}$ ) were measured by inductively coupled plasma-optical emission spectrometry (ICP-OES, Perkin-Elmer Optima 4300 DV; Perkin-Elmer, Shelton, CT), and are reported on a dry plant basis (in milligrams per gram). To validate the measurements, a blank (no plant tissues) and standard reference material (Spinach, 1570a; National Institute of Standards and Technology, Gaithersburg, MD) were also analyzed in ICP-OES after every 20 samples.

Experimental design and statistical analysis. The experiment used a completely randomized design with 10 plants per treatment per species. Two-way analysis of variance was performed for all plant growth parameters. Visual score was analyzed as multinomial data, whereas number of inflorescences and tillers were analyzed as negative binomial data. Means separation among treatments and species was adjusted using Tukey's method for multiplicity at $\alpha=0.05$. All statistical analyses were performed with the GENMOD and GLIMMIX procedures of SAS/STAT 14.3 in SAS (version 9.4; SAS Institute, Cary, NC).

\section{Results and Discussion}

Because ornamental grasses were irrigated with saline solution, the salinity in the leachate solution gradually increased (Fig. 1). Throughout the entire experiment, the EC of the leachate solution was around $1.9 \mathrm{dS} \cdot \mathrm{m}^{-1}$ for the control. Starting from the second irrigation, with saline solution at an $\mathrm{EC}$ of 5.0 or $10.0 \mathrm{dS} \cdot \mathrm{m}^{-1}$, the EC of the leachate solution was consistently greater than the control (all $P$ values $<0.0045$ ). The EC of the leachate solution increased from 4.1 to $9.6 \mathrm{dS} \cdot \mathrm{m}^{-1}$ and from 5.8 to 18.0 $\mathrm{dS} \cdot \mathrm{m}^{-1}$ when irrigated with saline solution at an EC of 5.0 and $10.0 \mathrm{dS} \cdot \mathrm{m}^{-1}$, respectively. These results indicate that salts accumulated in the growing substrate, which can be seen in the final soil ECe, which was measured using a saturated soil paste technique (Table 2, Fig. 2). After 16 irrigations with saline solution at an EC of $5.0 \mathrm{dS} \cdot \mathrm{m}^{-1}$, the soil ECe values were $8.2,12.7,12.5$, and $8.6 \mathrm{dS} \cdot \mathrm{m}^{-1}$ for $E$. spectabilis, M. sinensis, P. virgatum, and $S$. scoparium, respectively (Fig. 2); saline solution at an EC of $10.0 \mathrm{dS} \cdot \mathrm{m}^{-1}$ further increased the soil ECe to 15.7, 22.1, 22.5, and $21.9 \mathrm{dS} \cdot \mathrm{m}^{-1}$, respectively (Fig. 2).

Saline solution irrigation affected plant visual quality, with different responses among ornamental grass species (Table 2). Panicum virgatum and $S$. scoparium exhibited no foliar salt damage when irrigated with saline solution at an EC of 5.0 or $10.0 \mathrm{dS} \cdot \mathrm{m}^{-1}$ (Table 3). Eragrostis spectabilis showed minimal foliar salt damage when irrigated with saline solution at an EC of $5.0 \mathrm{dS} \cdot \mathrm{m}^{-1}$, but had slight foliar salt damage, with an average visual score of 3.6 when irrigated with saline solution at an EC of 10.0 $\mathrm{dS} \cdot \mathrm{m}^{-1}$. Miscanthus sinensis displayed slight foliar salt damage, with average visual scores of 3.7 and 3.3, respectively, when irrigated with saline solution at an EC of 5.0 or 10.0 $\mathrm{dS} \cdot \mathrm{m}^{-1}$. These results indicate that four ornamental grasses had a strong tolerance to the salinity levels tested in this study. Similarly, Muhlenbergia lindheimeri Hitchc. (blue muhly grass) had an acceptable visual quality when they were grown for 8 weeks in a hydroponic system with saline solution at an EC of 5.0 or $10.0 \mathrm{dS} \cdot \mathrm{m}^{-1}$ achieved by the addition of a 2:1 ratio of $\mathrm{NaCl}$ to $\mathrm{CaCl}_{2}$ in half-strength Hoagland solution (McKenney et al., 2016). In a previous study, sand ryegrass, pink muhly grass, and fountain grass irrigated with saline solution at an EC of 5.0 or $10 \mathrm{dS} \cdot \mathrm{m}^{-1}$ for 18 weeks also had a good visual quality, with minimal foliar salt damage (Sun and Palmer, 2018).

Saline solution irrigation affected plant height and leaf area, but there were no interactive effects between salt treatment and ornamental grass species (Table 2). Regardless of species, all ornamental grasses irrigated with saline solution at an EC of 5.0 $\mathrm{dS} \cdot \mathrm{m}^{-1}$ had a similar height to the control (Fig. 3A); however, ornamental grasses were $15 \%$ shorter than the control when irrigated with saline solution at an EC of $10.0 \mathrm{dS} \cdot \mathrm{m}^{-1}$. The leaf area of all ornamental grasses irrigated with saline solution at an EC of 5.0 or $10.0 \mathrm{dS} \cdot \mathrm{m}^{-1}$ decreased by $22 \%$ and $47 \%$, respectively, compared with the control (Fig. 3B). These results are in line with previous reports that salinity stress inhibited plant growth and leaf expansion (Sun and Palmer, 2018; Sun et al., 2015a; Wu et al., 2016). For example, all ornamental grass and grasslike plants irrigated with saline solution at an $\mathrm{EC}$ of $10.0 \mathrm{dS} \cdot \mathrm{m}^{-1}$ were $10 \%$ to $38 \%$ shorter than the control at 9 weeks after the initiation of treatment, but they had a similar height to the control when irrigated with saline solution at an EC of $5.0 \mathrm{dS} \cdot \mathrm{m}^{-1}$, except Chasmanthium latifolium (Michx.) Yates (indian sea oats), pink muhly grass, and fountain grass (Sun and Palmer, 2018). Plant 
Table 2. A summary of analysis of variance for the effects of irrigation water electrical conductivity (EC), plant species, and their interactions on saturated soil extract $\left(\mathrm{EC}_{\mathrm{e}}\right)$, plant visual score, height, leaf area, number of inflorescences, number of tillers, shoot dry weight (DW), relative chlorophyll content [soil-plant analysis development (SPAD) reading], net photosynthesis rate $\left(\mathrm{P}_{\mathrm{n}}\right)$, stomatal conductance $\left(g_{\mathrm{S}}\right)$, and transpiration rate $(\mathrm{E})$ of ornamental grasses irrigated with a nutrient solution at an EC of $1.2 \mathrm{dS} \cdot \mathrm{m}^{-1}$ (control), or a saline solution at an EC of $5.0 \mathrm{dS} \cdot \mathrm{m}^{-1}$ (EC 5) or $10.0 \mathrm{dS} \cdot \mathrm{m}^{-1}(\mathrm{EC} 10)$ in a greenhouse. ${ }^{\mathrm{z}}$

\begin{tabular}{|c|c|c|c|c|c|c|c|c|c|c|c|}
\hline \multirow[b]{2}{*}{ Source } & \multicolumn{11}{|c|}{ Analysis of variance } \\
\hline & $\overline{\text { Soil ECe }}{ }^{\mathrm{y}}$ & Visual score & $\mathrm{Ht}$ & Leaf area & Inflorescence (no.) & Tiller (no.) & Shoot DW & SPAD & $P_{n}$ & $g_{\mathrm{S}}$ & $\bar{E}$ \\
\hline$\overline{\mathrm{EC}}$ & $* * *$ & $* * *$ & $* * *$ & $* * *$ & $* * *$ & $* * *$ & $* * *$ & $* * *$ & $* *$ & $* * *$ & $* * *$ \\
\hline Species & $* * *$ & $* * *$ & $* * *$ & $* * *$ & $* * *$ & $* * *$ & $* * *$ & * & $* * *$ & $* * *$ & $* * *$ \\
\hline EC $\times$ species & $*$ & $* * *$ & NS & NS & $*$ & $* *$ & NS & $* *$ & $*$ & $*$ & NS \\
\hline
\end{tabular}

${ }^{\mathrm{z}}$ Saline solution was created by adding sodium chloride $(\mathrm{NaCl})$ and calcium chloride $\left(\mathrm{CaCl}_{2}\right)$ to the nutrient solution.

${ }^{\mathrm{y}}$ Soil ECe was collected using a saturated soil paste technique (Gavlak et al., 1994).

NS, *, **, ${ }^{* * *}$ Nonsigificant or significant at $P<0.05,0.01$, or 0.001 , respectively.

\section{- Control EC $5 \square$ EC 10}

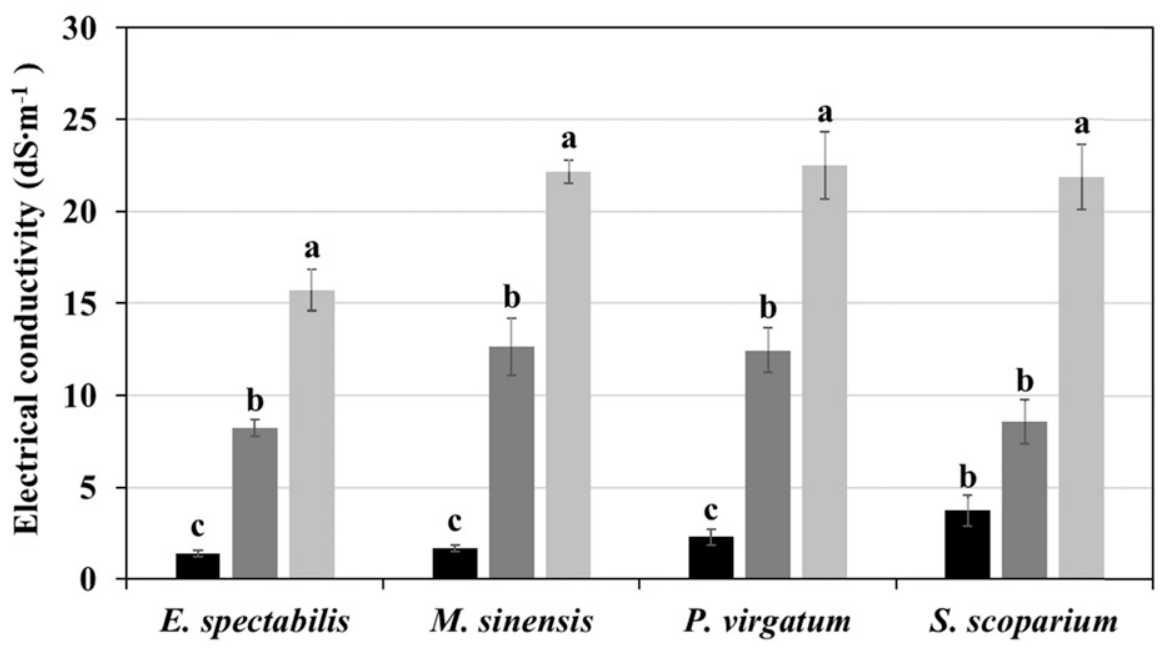

Fig. 2. Electrical conductivity (EC) of the substrate used for growing ornamental grasses. Plants were irrigated roughly every $4 \mathrm{~d}$ with a nutrient solution at an $\mathrm{EC}$ of $1.2 \mathrm{dS} \cdot \mathrm{m}^{-1}$ (control), or a saline solution at an EC of 5.0 $\mathrm{dS} \cdot \mathrm{m}^{-1}$ (EC 5) or $10.0 \mathrm{dS} \cdot \mathrm{m}^{-1}$ (EC 10). A saturated soil paste technique (Gavlak et al., 1994) was used to determine the saturated soil extract of the growing substrate. Vertical bars represent SEs of three replications.

height of blue muhly grass and Carex tumulicola Mack. (foothill sedge) were barely affected by increasing salinity until an EC of $5.0 \mathrm{dS} \cdot \mathrm{m}^{-1}$, but declined significantly at an EC of $10.0 \mathrm{dS} \cdot \mathrm{m}^{-1}$ at 8 weeks of exposure to saline water in a hydroponic system (McKenney et al., 2016). Saline solution at an EC of $10.0 \mathrm{dS} \cdot \mathrm{m}^{-1}$ also reduced the leaf area of indian sea oats, Juncus effusus L. (common rush), and fountain grass at 9 weeks after the initiation of treatment (Sun and Palmer, 2018). This is one of the adaptation strategies against salt-induced water deficit, during which plants reduce plant growth and leaf expansion to prevent water loss.

Saline solution irrigation influenced the number of inflorescences and tillers with varying responses among ornamental grass species (Table 2). No M. sinensis plants flowered during the entire experimental period (Table 3). Compared with the control, the number of inflorescences of E. spectabilis and $P$. virgatum reduced by $34 \%$ and $29 \%$, respectively, when irrigated with saline solution at an EC of $5.0 \mathrm{dS} \cdot \mathrm{m}^{-1}$; and by $40 \%$ and $59 \%$, respectively, when irrigated with saline solution at an EC of $10.0 \mathrm{dS} \cdot \mathrm{m}^{-1}$. However, there was no significance among treatments for the number of inflorescences of S. scoparium. Increasing salinity stress has been observed to affect the flowering of ornamen- tal grasses negatively (Scheiber et al., 2008; EC of 5.0 or $10.0 \mathrm{dS} \cdot \mathrm{m}^{-1}$ reduced the number of tillers of E. spectabilis by $27 \%$ and $40 \%$, respectively, compared with the control (Table 3). Saline solution at an EC of 10.0 $\mathrm{dS} \cdot \mathrm{m}^{-1}$ also decreased the number of tillers of $S$. scoparium by $52 \%$, but this was not the case for $M$. sinensis and $P$. virgatum, which tended to have less tillers. In a previous study, Carex vulpinoidea Michx. (fox sedge) and fountain grass produced $26 \%$ and $23 \%$ fewer tillers, respectively, compared with the control, when irrigated with saline solution at an EC of $10.0 \mathrm{dS} \cdot \mathrm{m}^{-1}$ for 18 weeks (Sun and Palmer, 2018). However, this saline water irrigation slightly reduced the number of tillers of blue grama, 'Blue Dune' sand ryegrass, indian sea oats, common rush, and pink muhly grass.

Saline solution irrigation had a significant effect on the shoot dry weight, and all ornamental grass species showed similar responses to salt treatments (Table 2). Regardless of species, the shoot dry weight of all ornamental grasses reduced by $25 \%$ and $46 \%$ when irrigated with saline solution at an EC of 5.0 or $10.0 \mathrm{dS} \cdot \mathrm{m}^{-1}$, respectively, compared with the control (Fig. 4A). In addition, E. spectabilis and $M$. sinensis produced the greatest shoot dry weight, but $S$. scoparium accumulated the least (Fig. 4A). It was not Sun and Palmer, 2018). Saline solution at an surprising to see this result because previous studies have observed that increasing salinity stress inhibited plant growth and development of ornamental grasses significantly (Alvarez, 2006; LeCompte et al., 2016; Zhang et al., 2012).

Saline solution irrigation affected the relative chlorophyll content (SPAD reading) (Tables 2 and 4). The SPAD readings of $E$. spectabilis and $S$. scoparium were not significant among treatments. Saline solution at an EC of $10.0 \mathrm{dS} \cdot \mathrm{m}^{-1}$ reduced the SPAD readings of M. sinensis by $11 \%$. This result is similar to the findings observed by Sun et al. (2015b): The SPAD reading of a wild $M$. sinensis population decreased with increasing $\mathrm{NaCl}$ concentrations and stress duration. Salinity may inhibit chlorophyll synthesis and/or accelerate its degradation (Netondo et al., 2004; Zhao et al., 2007). Panicum virgatum irrigated with saline solution at an EC of 5.0 and $10.0 \mathrm{dS} \cdot \mathrm{m}^{-1}$ had an increase of $10 \%$ and $6 \%$ in the SPAD readings, respectively. This is also true for switchgrass cultivars evaluated previously (Sun et al., 2018).

Saline solution irrigation had a significant influence on the leaf $\mathrm{P}_{\mathrm{n}}$ and $g_{\mathrm{S}}$ of ornamental grasses, and varying responses were observed among ornamental grass species (Table 2). Leaf $\mathrm{P}_{\mathrm{n}}$ of $E$. spectabilis and $P$. virgatum irrigated with saline solution at an EC of 10.0 $\mathrm{dS} \cdot \mathrm{m}^{-1}$ decreased by $49 \%$ and $36 \%$, respectively, compared with the control, but this was not the case for those irrigated with saline solution at an EC of $5.0 \mathrm{dS} \cdot \mathrm{m}^{-1}$ (Table 4). When irrigated with saline solution at an EC of 5.0 and $10.0 \mathrm{dS} \cdot \mathrm{m}^{-1}$, the $\mathrm{P}_{\mathrm{n}}$ of $M$. sinensis reduced by $31 \%$ and $36 \%$, respectively, and that of S. scoparium decreased by $32 \%$ and $60 \%$, respectively, compared with the control. Salinity stress has been documented to inhibit plant photosynthesis. Sun et al. (2015b) reported that $M$. sinensis plants irrigated with saline solution at an EC of 6.1, $10.5,23.6$, and $27.0 \mathrm{dS} \cdot \mathrm{m}^{-1}$ had a decrease of $21 \%, 35 \%, 61 \%$, and $79 \%$ in photosynthesis, respectively, for accession JM0119; and $26 \%, 47 \%, 72 \%$, and $89 \%$, respectively, for accession JM0099. This is similar to our results, although $20 \mathrm{~N}-8.8 \mathrm{P}-16.6 \mathrm{~K}$ fertilizer solutions containing $\mathrm{NaCl}$ and $\mathrm{CaCl}_{2}$ at a 5:1-M ratio were used for irrigating $M$. sinensis plants daily for $30 \mathrm{~d}$. $P$. virgatum tolerant lines showed about $50 \%$ reduction in photosynthesis, and sensitive lines exhibited about $90 \%$ reduction after being irrigated for $30 \mathrm{~d}$ with $250 \mathrm{~mm} \mathrm{NaCl}$ solution (EC, $\approx 21 \mathrm{dS} \cdot \mathrm{m}^{-1}$ ) (Kim et al., 2016). Saline solution irrigation 
Table 3. Visual score, number of inflorescences, and number of tillers of ornamental grasses irrigated with a nutrient solution at an electrical conductivity (EC) of $1.2 \mathrm{dS} \cdot \mathrm{m}^{-1}$ (control), or a saline solution at an EC of $5.0 \mathrm{dS} \cdot \mathrm{m}^{-1}$ (EC 5) or $10.0 \mathrm{dS} \cdot \mathrm{m}^{-1}$ (EC 10) in a greenhouse. ${ }^{\mathrm{z}}$

\begin{tabular}{|c|c|c|c|c|c|c|c|c|c|}
\hline \multirow[b]{2}{*}{ Species } & \multicolumn{3}{|c|}{ Visual score ${ }^{y}$} & \multicolumn{3}{|c|}{ Inflorescence (no.) } & \multicolumn{3}{|c|}{ Tiller (no.) } \\
\hline & Control & EC 5 & EC 10 & Control & EC 5 & EC 10 & Control & EC 5 & EC 10 \\
\hline M. sinensis & $5.0 \mathrm{aA}$ & $3.7 \mathrm{bB}$ & $3.3 \mathrm{cB}$ & $-^{\mathrm{v}}$ & - & - & $90.2 \mathrm{aAB}$ & $70.6 \mathrm{aB}$ & $75.7 \mathrm{aA}$ \\
\hline
\end{tabular}

${ }^{\mathrm{z}}$ Saline solution was created by adding sodium chloride $(\mathrm{NaCl})$ and calcium chloride $\left(\mathrm{CaCl}_{2}\right)$ to the nutrient solution. Plants were harvested after the sixteenth irrigation ( $65 \mathrm{~d}$ after the initiation of treatment).

$\mathrm{y}_{0}=$ dead; $1=$ severe foliar salt damage ( $>90 \%$ leaves with burn and necrosis at the top part of leaf blade); $2=$ moderate $(50 \%$ to $90 \%)$ foliar salt damage; $3=$ slight $(<50 \%)$ foliar salt damage; 4 = good quality with minimal foliar salt damage; and $5=$ excellent without foliar salt damage (Sun et al., 2015a).

${ }^{x}$ Means with the same lowercase letters within a row and a dependent variable are not significantly different among treatments by Tukey's method for multiplicity at $\alpha=0.05$.

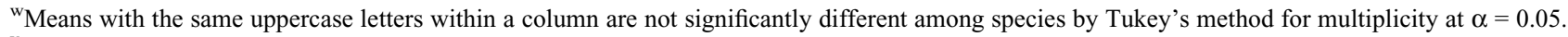

${ }^{v}$ No plants flowered during the entire experimental period.

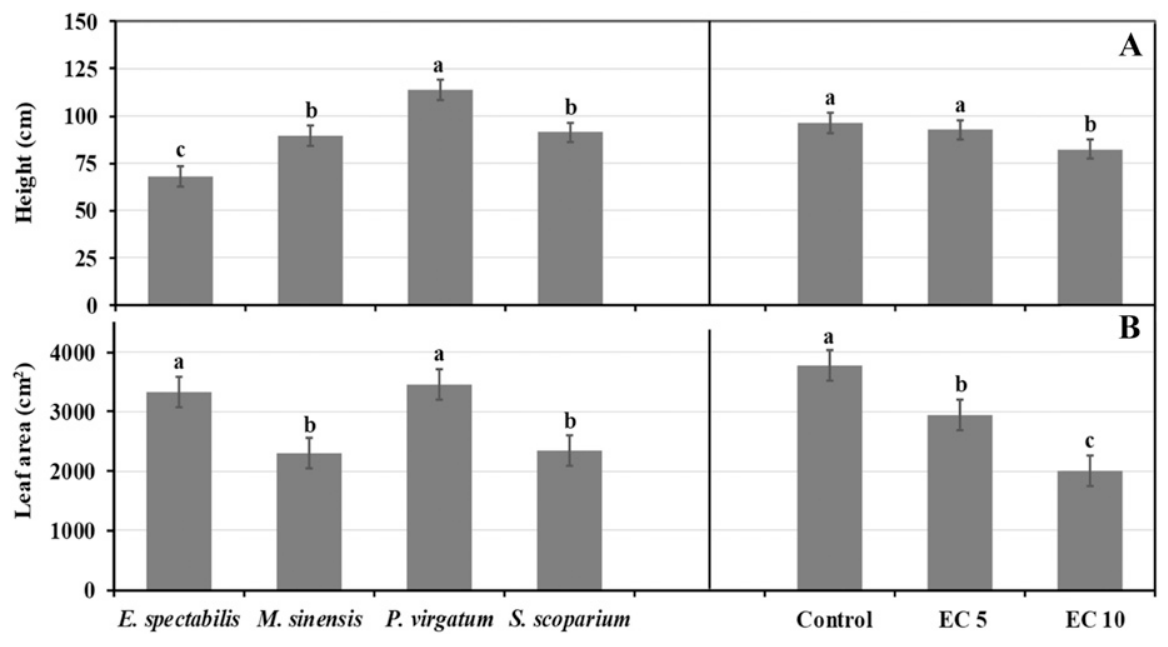

Fig. 3. Plant height (A) and leaf area (B) of ornamental grasses irrigated with a nutrient solution at an electrical conductivity (EC) of $1.2 \mathrm{dS} \cdot \mathrm{m}^{-1}$ (control), or a saline solution at an EC of $5.0 \mathrm{dS} \cdot \mathrm{m}^{-1}$ (EC 5) or $10.0 \mathrm{dS} \cdot \mathrm{m}^{-1}$ (EC 10) in a greenhouse. Saline solution was created by adding sodium chloride and calcium chloride to the nutrient solution. Plants were harvested after the 16th irrigation ( $65 \mathrm{~d}$ after the initiation of treatment). Vertical bars represent SES of 10 replications.

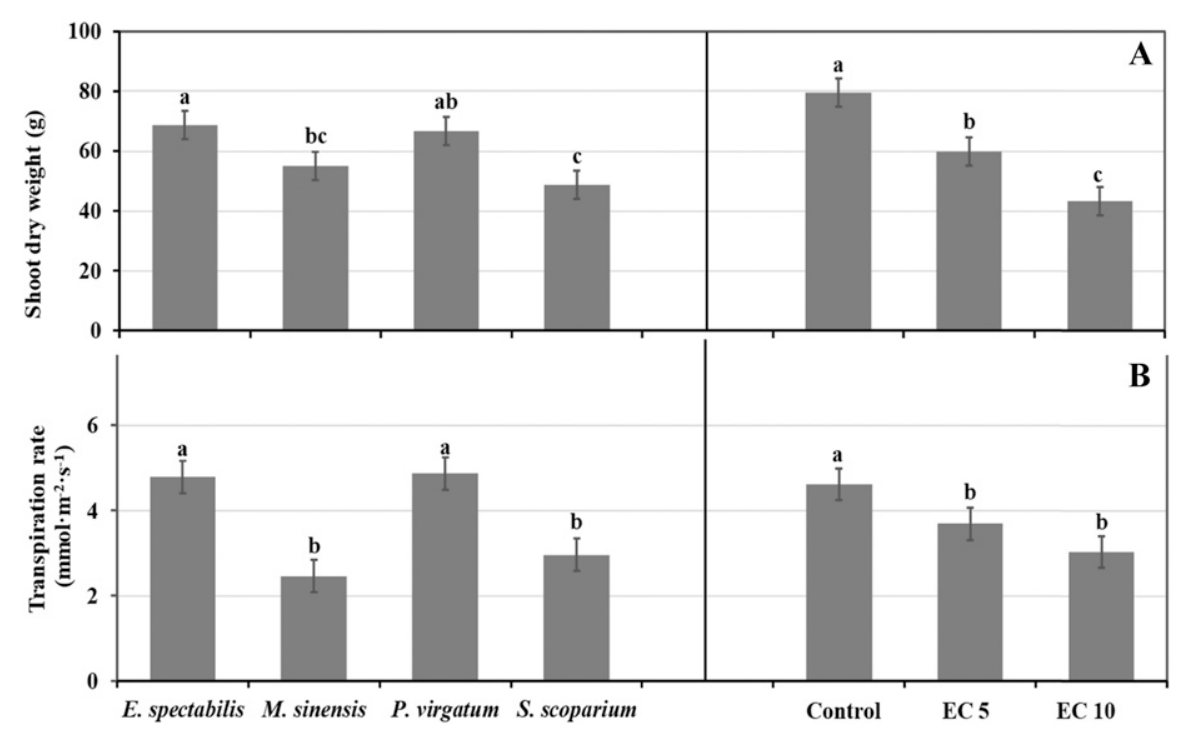

Fig. 4. Shoot dry weight (A) and transpiration rate (B) of ornamental grasses irrigated with a nutrient solution at an electrical conductivity (EC) of $1.2 \mathrm{dS} \cdot \mathrm{m}^{-1}$ (control), or a saline solution at an EC of 5.0 $\mathrm{dS} \cdot \mathrm{m}^{-1}$ (EC 5) or $10.0 \mathrm{dS} \cdot \mathrm{m}^{-1}$ (EC 10) in a greenhouse. Saline solution was created by adding sodium chloride and calcium chloride to the nutrient solution. Plants were harvested after the 16th irrigation ( $65 \mathrm{~d}$ after the initiation of treatment). Vertical bars represent SES of 10 and 6 measurements for shoot dry weight and transpiration rate, respectively. did not affect the $g_{\mathrm{S}}$ of $P$. virgatum (Table 4). The $g_{\mathrm{S}}$ of $M$. sinensis and $S$. scoparium plants irrigated with saline solution at an EC of 5.0 $\mathrm{dS} \cdot \mathrm{m}^{-1}$ decreased by $44 \%$ and $37 \%$, respectively; and that of E. spectabilis, M. sinensis, and $S$. scoparium plants irrigated with saline solution at an EC of $10.0 \mathrm{dS} \cdot \mathrm{m}^{-1}$ decreased by $59 \%, 42 \%$, and, $62 \%$, respectively, compared with the control. Sun et al. (2015b) also observed that salinity stress strongly reduced the $g_{\mathrm{S}}$ of M. sinensis accessions (JM0119 and JM0099). Saline solution irrigation affected leaf transpiration rate of ornamental grasses, but no interactive effect was detected between ornamental grass species and the EC level of saline solution (Table 2). Regardless of ornamental grass species, all plants irrigated with saline solution at an EC of 5.0 and 10.0 $\mathrm{dS} \cdot \mathrm{m}^{-1}$ had $34 \%$ and $20 \%$ reduction in the transpiration rate, respectively, compared with the control (Fig. 4B). When the salt-induced water deficit continues to increase, stomatal closure occurs and transpiration decreases.

Mineral analyses. The $\mathrm{Na}^{+}$and $\mathrm{Cl}^{-}$concentrations in the leaf tissue of ornamental grasses were affected by increasing salinity levels, and also varied among ornamental grass species (Table 5). Along with increasing salinity, $M$. sinensis accumulated the greatest amount of $\mathrm{Na}^{+}$ions, whereas $S$. scoparium took up the least. Compared with the control, the leaf $\mathrm{Na}^{+}$concentration of $E$. spectabilis, $M$. sinensis, $P$. virgatum, and $S$. scoparium increased 4.0, 18.8, 4.5, and 1.6 times, respectively, when irrigated with saline solution at an EC of $5.0 \mathrm{dS} \cdot \mathrm{m}^{-1}$; and increased 14.3, 52.6, 5.3, and 1.7 times, respectively, when irrigated with saline solution at an EC of $10.0 \mathrm{dS} \cdot \mathrm{m}^{-1}$. The fact that leaf $\mathrm{Na}^{+}$concentration increased with increasing salinity levels of irrigation water has been observed previously. M. sinensis (accession JM0099) grown in peatmoss and irrigated with saline solution at an EC of 3.2, 6.1, and $10.5 \mathrm{dS} \cdot \mathrm{m}^{-1}$ for $30 \mathrm{~d}$ in a greenhouse accumulated about $4.6,6.9$, and $12.7 \mathrm{mg} \cdot \mathrm{g}^{-1} \mathrm{Na}^{+}$ in the leaves (Sun et al., 2015b). Switchgrass cultivars grown in a high-porosity growing mix ( 3 peatmoss: 2 perlite) and watered with saline solution at an EC of 5.0 and 10.0 $\mathrm{dS} \cdot \mathrm{m}^{-1}$ for 4 weeks had 0.5 to $1.6 \mathrm{mg} \cdot \mathrm{g}^{-1} \mathrm{Na}^{+}$ in the leaves (Sun et al., 2018). The values documented in these reports are similar to the leaf $\mathrm{Na}^{+}$concentrations of $M$. sinensis and $P$. 
Table 4. Relative chlorophyll content [soil-plant analysis development (SPAD) reading], leaf net photosynthesis rate $\left(\mathrm{P}_{\mathrm{n}}\right)$, and stomatal conductance $\left(g_{\mathrm{S}}\right)$ of ornamental grasses irrigated with a nutrient solution at an electrical conductivity (EC) of $1.2 \mathrm{dS} \cdot \mathrm{m}^{-1}$ (control), or a saline solution at an EC of $5.0 \mathrm{dS} \cdot \mathrm{m}^{-1}$ (EC 5) or $10.0 \mathrm{dS} \cdot \mathrm{m}^{-1}(\mathrm{EC} 10)$ in a greenhouse. ${ }^{\mathrm{z}}$

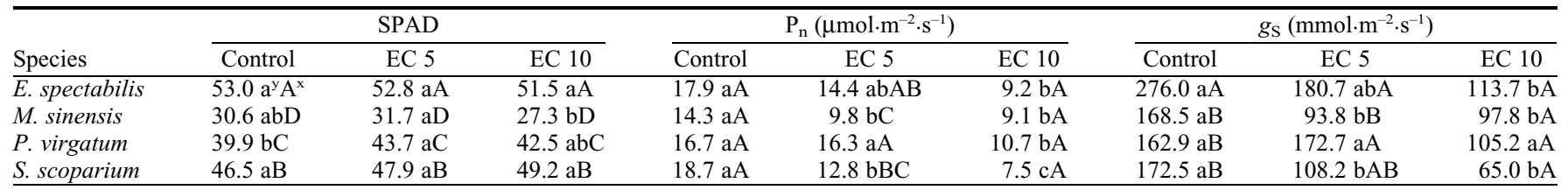

${ }^{\mathrm{z}}$ Saline solution was created by adding sodium chloride $(\mathrm{NaCl})$ and calcium chloride $\left(\mathrm{CaCl}_{2}\right)$ to the nutrient solution. Plants were harvested after the sixteenth irrigation ( $65 \mathrm{~d}$ after the initiation of treatment).

${ }^{\mathrm{y}}$ Means with the same lowercase letters within a row and a dependent variable are not significantly different among treatments by Tukey's method for multiplicity at $\alpha=0.05$.

${ }^{\mathrm{x}}$ Means with the same uppercase letters within a column are not significantly different among species by Tukey's method for multiplicity at $\alpha=0.05$.

Table 5. Macronutrients and micronutrients of ornamental grasses irrigated with a nutrient solution at an electrical conductivity (EC) of $1.2 \mathrm{dS} \cdot \mathrm{m}^{-1}$ (control), or a saline solution at an EC of $5.0 \mathrm{dS} \cdot \mathrm{m}^{-1}$ (EC 5) or $10.0 \mathrm{dS} \cdot \mathrm{m}^{-1}$ (EC 10) in a greenhouse. ${ }^{\mathrm{z}}$

\begin{tabular}{|c|c|c|c|c|c|c|c|c|}
\hline \multirow[b]{2}{*}{ Species } & \multirow[b]{2}{*}{ Treatment } & \multicolumn{7}{|c|}{ Mineral concn (mg. $\mathrm{g}^{-1}$ dry wt) } \\
\hline & & $\mathrm{Na}^{+}$ & $\mathrm{Cl}^{-}$ & $\mathrm{Ca}^{2+}$ & $\mathrm{K}^{+}$ & $\mathrm{Mg}^{2+}$ & $\mathrm{Zn}^{2+}$ & $\mathrm{Mn}^{2+}$ \\
\hline E. spectabilis & EC 5 & $1.41 \mathrm{~b}$ & $10.81 \mathrm{~b}$ & $5.48 \mathrm{~b}$ & $15.37 \mathrm{a}$ & $2.57 \mathrm{ab}$ & $0.08 \mathrm{ab}$ & $0.36 \mathrm{a}$ \\
\hline \multirow[t]{3}{*}{ M. sinensis } & Control & $0.18 \mathrm{c}$ & $2.62 \mathrm{c}$ & $3.99 \mathrm{~b}$ & $21.37 \mathrm{a}$ & $3.17 \mathrm{a}$ & $0.02 \mathrm{a}$ & $0.14 \mathrm{~b}$ \\
\hline & EC 5 & $3.47 \mathrm{~b}$ & $16.29 \mathrm{~b}$ & $6.57 \mathrm{~b}$ & $17.14 \mathrm{~b}$ & $3.00 \mathrm{a}$ & $0.02 \mathrm{a}$ & $0.39 \mathrm{a}$ \\
\hline & EC 10 & $9.37 \mathrm{a}$ & $31.59 \mathrm{a}$ & $12.22 \mathrm{a}$ & $15.44 \mathrm{~b}$ & $2.73 \mathrm{a}$ & $0.03 \mathrm{a}$ & $0.55 \mathrm{a}$ \\
\hline P. virgatum & Control & $0.23 \mathrm{~b}$ & $2.68 \mathrm{~b}$ & $2.52 \mathrm{a}$ & $21.73 \mathrm{a}$ & $3.12 \mathrm{a}$ & $0.02 \mathrm{a}$ & $0.22 \mathrm{~b}$ \\
\hline \multirow[t]{3}{*}{ S. scoparium } & Control & $0.43 \mathrm{~b}$ & $2.78 \mathrm{~b}$ & $2.53 \mathrm{~b}$ & $20.28 \mathrm{a}$ & $2.26 \mathrm{a}$ & $0.03 \mathrm{a}$ & $0.23 \mathrm{~b}$ \\
\hline & EC 5 & $1.14 \mathrm{a}$ & $8.35 \mathrm{a}$ & $5.72 \mathrm{a}$ & $16.98 \mathrm{~b}$ & $2.30 \mathrm{a}$ & $0.03 \mathrm{a}$ & $0.44 \mathrm{a}$ \\
\hline & EC 10 & $1.17 \mathrm{a}$ & $10.31 \mathrm{a}$ & $7.23 \mathrm{a}$ & $14.65 \mathrm{~b}$ & $2.01 \mathrm{a}$ & $0.03 \mathrm{a}$ & $0.55 \mathrm{a}$ \\
\hline \multicolumn{2}{|l|}{ Species } & $* * *$ & $* * *$ & $* * *$ & $* * *$ & $* * *$ & $* * *$ & * \\
\hline \multicolumn{2}{|l|}{ Treatment } & $* * *$ & $* * *$ & $* * *$ & $* * *$ & ** & $* * *$ & *** \\
\hline \multicolumn{2}{|c|}{ Species $\times$ treatment } & *** & $* * *$ & ** & NS & NS & $* * *$ & * \\
\hline
\end{tabular}

${ }^{\mathrm{z}}$ Saline solution was created by adding sodium chloride $(\mathrm{NaCl})$ and calcium chloride $\left(\mathrm{CaCl}_{2}\right)$ to the nutrient solution. Plants were harvested after the 16th irrigation ( $65 \mathrm{~d}$ after the initiation of treatment).

${ }^{\mathrm{y}}$ Within species, means with the same lowercase letters within a column and a dependent variable are not significantly different among treatments by Tukey's method for multiplicity at $\alpha=0.05$.

${ }_{\mathrm{NS},}^{*},{ }^{* *},{ }^{* * *}$ Nonsignificant or significant at $P<0.05,0.01$, or 0.001 , respectively.

virgatum in our study, although different growing substrates and varied durations of saline solution application were used. To the best of our knowledge, there were no reports of the leaf $\mathrm{Na}^{+}$concentrations of E. spectabilis and $S$. scoparium irrigated with saline water irrigation. However, the values recorded in our study were much less than those reported by LeCompte et al. (2016), who found that pink muhly grass had 11.7 to $31.4 \mathrm{mg} \cdot \mathrm{g}^{-1} \mathrm{Na}^{+}$in the leaves when grown in a substrate ( 5 pinebark: 3 peat: 1 perlite) and irrigated with 4000 to $10,000 \mathrm{mg} \cdot \mathrm{L}^{-1} \mathrm{NaCl}$ $\left(\approx 5.0-12.5 \mathrm{dS} \cdot \mathrm{m}^{-1}\right)$ for 15 weeks. The discrepancy in the leaf $\mathrm{Na}^{+}$concentrations in these studies might result from different plant species and different durations of saline water irrigation.

Compared with the control, E. spectabilis, $M$. sinensis, $P$. virgatum, and $S$. scoparium had $4.3,5.2,2.6$, and 2.0 times more $\mathrm{Cl}^{-}$ions in the leaves, respectively, when irrigated with saline solution at an EC of $5.0 \mathrm{dS} \cdot \mathrm{m}^{-1}$ (Table 5). The $\mathrm{Cl}^{-}$concentration in the leaf tissue of E. spectabilis, M. sinensis, $P$. virgatum, and $S$. scoparium increased an additional 9.4, 11.1, 2.8, and 2.7 times, respectively, when irrigated with saline solution at an EC of $10.0 \mathrm{dS} \cdot \mathrm{m}^{-1}$. Sun et al. (2018) reported that switchgrass irrigated with saline solution at an EC of 5.0 and $10.0 \mathrm{dS} \cdot \mathrm{m}^{-1}$ accumulated about 10.8 to 13.5 and 12.7 to $15.3 \mathrm{mg} \cdot \mathrm{g}^{-1} \mathrm{Cl}^{-}$ions in the leaves, respectively.
Pink muhly grass irrigated with 2000 to 4000 $\mathrm{mg} \cdot \mathrm{L}^{-1} \mathrm{NaCl}\left(\mathrm{EC}, \approx 2.5-5.0 \mathrm{dS} \cdot \mathrm{m}^{-1}\right)$ had 15.6 to $17.4 \mathrm{mg} \cdot \mathrm{g}^{-1} \mathrm{Cl}^{-}$ions in the leaves (LeCompte et al., 2016). These values are similar to or slightly greater than our results. $M$. sinensis (accession JM0099) watered with saline solution at an EC of 3.2, 6.1, and $10.5 \mathrm{dS} \cdot \mathrm{m}^{-1}$ accumulated about $28.4,32.0$, and $49.7 \mathrm{mg} \cdot \mathrm{g}^{-1}$ $\mathrm{Cl}^{-}$ions in the leaves (Sun et al., 2015b), whereas pink muhly grass irrigated with 6000 to $10,000 \mathrm{mg} \cdot \mathrm{L}^{-1} \mathrm{NaCl}\left(\mathrm{EC}, \approx 7.5-12.5 \mathrm{dS} \cdot \mathrm{m}^{-1}\right)$ had 47.6 to $60.7 \mathrm{mg} \cdot \mathrm{g}^{-1} \mathrm{Cl}^{-}$ions in the leaves (LeCompte et al., 2016). The values in these studies are much greater than our observations. Factors such as duration of saline water irrigation and plant species contributed to the differences in leaf $\mathrm{Cl}^{-}$concentration.

Although leaf $\mathrm{Na}^{+}$and $\mathrm{Cl}^{-}$concentrations correlated negatively with visual score $(P<$ $0.0001)$, all ornamental grass species still exhibited a good visual quality. Both leaf $\mathrm{Na}^{+}$ and $\mathrm{Cl}^{-}$concentrations also correlated negatively with leaf area $(P=0.05$ and 0.02 , respectively) and shoot dry weight $(P=0.08$ and 0.03 , respectively), but not with plant height and number of tillers. These results indicate that leaf $\mathrm{Na}^{+}$and $\mathrm{Cl}^{-}$concentrations are still not high enough to cause salt damage to the ornamental grasses. It might be also true that these four ornamental grass species can tolerate the levels of $\mathrm{Na}^{+}$and $\mathrm{Cl}^{-}$ions or even greater in the leaves. In this case, osmotic effects might have the most influences on plant growth and development (Munns and Tester, 2008). High $\mathrm{Na}^{+}$and/or $\mathrm{Cl}^{-1}$ accumulation in leaf tissue has been reported to damage the chloroplasts and inhibit photosynthesis (Taiz and Zeiger, 2015). Both leaf $\mathrm{Na}^{+}$and $\mathrm{Cl}^{-}$concentrations correlated negatively with $\mathrm{P}_{\mathrm{n}}(P=0.02$ and 0.004 , respectively), transpiration rate $(P=$ 0.02 and 0.01 , respectively $)$, and $g_{\mathrm{S}}(P=0.06$ and 0.02 , respectively), but not with SPAD. The $\mathrm{Na}^{+}$and $\mathrm{Cl}^{-}$concentrations in these ornamental grass species are high enough to inhibit plant photosynthesis.

The leaf $\mathrm{Ca}^{2+}$ concentrations of ornamental grasses were affected interactively by increasing salinity levels and ornamental grass species (Table 5). Schizachyrium scoparium accumulated $126 \%$ more $\mathrm{Ca}^{2+}$ ions in the leaves than the control when they were irrigated with saline solution at an EC of 5.0 $\mathrm{dS} \cdot \mathrm{m}^{-1}$, but this was not the case for the other three species (Table 5). All ornamental grass species irrigated with saline solution at an EC of $10.0 \mathrm{dS} \cdot \mathrm{m}^{-1}$ had one or two times more $\mathrm{Ca}^{2+}$ ions in the leaves than the control, with the exception of $P$. virgatum. Although $\mathrm{CaCl}_{2}$ is one of the components in the saline solution used in our study, the increase of the $\mathrm{Ca}^{2+}$ levels in the leaves was relatively small, 
which could result from selective uptake of $\mathrm{Na}^{+}$ions by ornamental grasses. Sun et al. (2018) reported that leaf $\mathrm{Ca}^{2+}$ concentration of six switchgrass cultivars watered with saline solution at an EC of 5.0 and 10.0 $\mathrm{dS} \cdot \mathrm{m}^{-1}$ ranged from 4.4 to $6.4 \mathrm{mg} \cdot \mathrm{g}^{-1}$, which is similar to the results in this study. However, pink muhly grass irrigated with 2000 to $10,000 \mathrm{mg} \cdot \mathrm{L}^{-1} \mathrm{NaCl}\left(\mathrm{EC}, \approx 2.5-12.5 \mathrm{dS} \cdot \mathrm{m}^{-1}\right)$ had 1.1 to $1.8 \mathrm{mg} \cdot \mathrm{g}^{-1} \mathrm{Ca}^{2+}$ in the leaves (LeCompte et al., 2016), which is much less than our results. Salinity dominated by sodium salts decreases the availability, transport, and mobility of $\mathrm{Ca}^{2+}$ to plant growth and may cause $\mathrm{Ca}^{2+}$ deficiency (Grattan and Grieve, 1999). It is better to add $\mathrm{CaCl}_{2}$ to the irrigation solution to avoid $\mathrm{Ca}^{2+}$ deficiency when salinity stress with sodium salts exists.

Increasing salinity affected the $\mathrm{K}^{+}$concentrations in the leaves of ornamental grasses (Table 5). Regardless of ornamental grass species, saline solution at an EC of 5.0 and $10.0 \mathrm{dS} \cdot \mathrm{m}^{-1}$ decreased the $\mathrm{K}^{+}$concentration by $17 \%$ and $21 \%$, respectively, compared with the control. This result is in line with previous observations on the leaf $\mathrm{K}^{+}$concentration of switchgrass cultivars (Sun et al., 2018) and M. sinensis accessions (Sun et al., 2015b), but not for pink muhly grass (LeCompte et al., 2016). High sodium salts have competitive effects on $\mathrm{K}^{+}$acquisition - a mechanism of osmotic adjustment for plants to protect themselves from salt stress (Grattan and Grieve, 1999; Taiz and Zeiger, 2015).

Increasing salinity also affected the $\mathrm{Mg}^{2+}$, $\mathrm{Zn}^{2+}$, and $\mathrm{Mn}^{2+}$ concentrations in the leaves of ornamental grasses (Table 5). Regardless of ornamental grass species, saline solution at an EC of 5.0 and $10.0 \mathrm{dS} \cdot \mathrm{m}^{-1}$ decreased the $\mathrm{Mg}^{2+}$ concentration by $11 \%$ and $18 \%$, respectively, compared with the control. However, no significance in the leaf $\mathrm{Mg}^{2+}$ concentration was observed in pink muhly grass (LeCompte et al., 2016). On average, saline solution at an EC of 5.0 and $10.0 \mathrm{dS} \cdot \mathrm{m}^{-1}$ increased the $\mathrm{Zn}^{2+}$ concentration by $19 \%$ and $34 \%$, respectively, and $\mathrm{Mn}^{2+}$ concentration by $113 \%$ and $154 \%$, respectively, compared with the control. Increasing salinity did not affect the $\mathrm{P}, \mathrm{S}$, and $\mathrm{Fe}^{3+}$ concentration in the leaves of all tested ornamental grasses (data not shown). However, leaf $\mathrm{P}$ concentrations in pink muhly grass increased linearly with increasing $\mathrm{NaCl}$ concentrations (LeCompte et al., 2016). Excessive $\mathrm{Na}^{+}$and $\mathrm{Cl}^{-}$uptake has been observed to induce mineral nutrient imbalance, resulting in nutritional disorders and reduced plant quality (Grattan and Grieve, 1999). The concentrations of those mineral nutrients were still in the normal range as no obvious symptoms of nutrient deficiency were observed in our study.

In conclusion, plant growth and photosynthesis of all four ornamental grasses reduced, to some extent, as a result of saline water irrigation. Minimum foliar salt damage on $P$. virgatum and $S$. scoparium and slight foliar salt damage on E. spectabilis and $M$. sinensis were observed. Although high levels of $\mathrm{Na}^{+}$and $\mathrm{Cl}^{-}$accumulated in the leaves of ornamental grasses, all plants were of acceptable visual quality and were considered marketable. Four ornamental grasses showed a very strong tolerance to saline irrigation water containing $\mathrm{NaCl}$ and $\mathrm{CaCl}_{2}$ salts in this research. Further study should be conducted during multiple growing seasons to assess plant growth and survival of all ornamental grasses in landscapes where saline irrigation water is used as well as in landscapes in saltprone areas and nearby coastal regions.

\section{Literature Cited}

Alvarez, E.E. 2006. Salt and drought tolerance of four ornamental grasses. University of Florida, Gainesville, FL, MS thesis.

Carter, C.T. and C.M. Grieve. 2006. Salt tolerance of floriculture crops, p. 279-287. In: M.A. Khan and D.J. Weber (eds.). Ecophysiology of high salinity tolerant plants. Springer Science + Business Media, Dordrecht, The Netherlands.

Cavins, T.J., B.E. Whipker, and W.C. Fonteno. 2008. Pourthru: A method for monitoring nutrition in the greenhouse. Acta Hort. 779:289-297.

Chen, L., Y. Sun, G. Niu, Q. Liu, and J. Altland 2017. Relative salt tolerance of eight Japanese barberry cultivars. HortScience 52:1810-1815.

Christova-Boal, D., R. Eden, and S. McFarlane. 1996. An investigation into greywater reuse for urban residential properties. Desalination 106:391-397.

Gavlak, R.G., D.A. Horneck, and R.O. Miller 1994. Plant, soil, and water reference methods for the western region. Western Regional Ext. Publ. (WREP) 125.

Grattan, S.R. and C.M. Grieve. 1999. Salinitymineral nutrient relations in horticultural crops. Scientia Hort. 78:127-157.

Grieve, C.M. 2011. Review irrigation of floricultural and nursery crops with saline wastewaters. Isr. J. Plant Sci. 59:187-196.

Grieve, C.M., S.R. Grattan, and E.V. Maas. 2012. Plant salt tolerance, p. 405-459. In: W.W. Wallender and K.K. Tanji (eds.). Agricultural salinity assessment and management. 2nd ed. ASCE Manual and Rpt. Eng. Practice No. 71. American Society of Civil Engineering, Reston, VA. Grieve, C.M., J.A. Poss, S.R. Grattan, D.L. Suarez, S.E. Benes, and P.H. Robinson. 2004. Evaluation of salt-tolerant forages for sequential water reuse systems II. Plant-ion relations. Agr. Water Mgt. 70:121-135.

Gunnell, J., J. Goodspeed, and R.M. Anderson 2015. Ornamental grasses in the landscape: A guide for the Intermountain West. Utah State Univ. Ext., Logan, UT. 18 Dec. 2018. <https:// digitalcommons.usu.edu/extension_curall/733/>.

Kim, J., Y. Liu, X. Zhang, B. Zhao, and K. Childs. 2016. Analysis of salt-induced physiological and proline changes in 46 switchgrass (Panicum virgatum) lines indicates multiple response modes. Plant Physiol. Biochem. 105:203-212.

Kratsch, H., S. Olsen, L. Rupp, G. Cardon, and R. Heflebower. 2008. Soil salinity and ornamental plant selection. Utah State Univ. Coop. Ext., Logan, UT. 18 Dec. 2018. <https:// digitalcommons.usu.edu>

LeCompte, J.S., A.N. Wright, C.M. LeBleu, and J.R. Kessler. 2016. Saline irrigation affects growth and leaf tissue nutrient concentration of three native landscape plant species. HortTechnology 26:309-313.

Liu, Q., Y. Sun, G. Niu, J. Altland, L. Chen, and L. Jiang. 2017. Morphological and physiological responses of ten ornamental taxa to saline water irrigation. HortScience 52:1816-1822.

McKenney, C.B., T.R. Mahato, and U.K. Schuch 2016. Salinity tolerance of ornamental grasses adapted to semi-arid environments. Acta Hort. 1112:95-100.
Missouri Botanical Garden. 2018. Eragrostis spectabilis, Miscanthus sinensis 'Gracillimus', Panicum virgatum 'Northwind', and Schizachyrium scoparium. St. Louis, MO. 18 Dec. 2018. <www. missouribotanicalgarden.org/PlantFinder $>$.

Munns, R. and M. Tester. 2008. Mechanisms of salinity tolerance. Annu. Rev. Plant Biol. 59:651-681.

Netondo, G.W., J.C. Onyango, and E. Beck. 2004. Sorghum and salinity: II. Gas exchange and chlorophyll fluorescence of sorghum under salt stress. Crop Sci. 44:806-811.

Niu, G. and R.I. Cabrera. 2010. Growth and physiological responses of landscape plants to saline water irrigation: A review. HortScience 45:1605-1609.

Niu, G., R. Cabrera, T. Starman, and C. Hall. 2011. Water conservation in ornamental plant production through the use of alternative water sources. HortTechnology 21:694-695.

Scheiber, S.M., D. Sandrock, E. Alvarez, and M.M. Brennan. 2008. Effect of salt spray concentration on growth and appearance of 'Gracillimus' maiden grass and 'Hameln' fountain grass. HortTechnology 18:34-38.

Schiavon, M., B. Leinauer, M. Serena, B. Maier, and R. Sallenave. 2014. Plant growth regulator and soil surfactants' effects on saline and deficit irrigated warm-season grasses: I. Turf quality and soil moisture. Crop Sci. 54:2815-2826.

Schiavon, M., B. Leinauer, M. Serena, R. Sallenave, and B. Maier. 2012. Bermudagrass and seashore paspalum establishment from seed using differing irrigation methods and water qualities. Agron. J. 104:706-714.

Sun, Y., G. Niu, G. Ganjegunte, and Y. Wu. 2018. Salt tolerance of six switchgrass cultivars. Agriculture 8(5):66.

Sun, Y., G. Niu, and C. Perez. 2015a. Relative salt tolerance of seven Texas Superstar ${ }^{\circledR}$ perennials. HortScience 50:1562-1566.

Sun, Y. and A. Palmer. 2018. Responses of ornamental grass and grasslike plants to saline water irrigation. HortTechnology 28:799-806.

Sun, Q., T. Yamada, and T. Takano. 2015b. Salinity effect on germination, growth, and photosynthesis, and ion accumulation in wild Miscanthus sinensis Anderss. Populations. Crop Sci. 54:2760-2771.

Taiz, L. and E. Zeiger. 2015. Plant physiology and development. 6th ed. Sinauer Associates, Sunderland, MA.

Tanji, K., S. Grattan, C. Grieve, A. Harivandi, L. Rollins, D. Shaw, B. Sheikh, and L. Wu. 2008. A comprehensive literature review on salt management guide for landscape irrigation with recycled water in coastal southern California. 18 Dec. 2018. <www.salinitymanagement.org>.

U.S. Department of Agriculture. 2015. 2014 Census of horticultural specialties, Table 25. Washington, DC. 18 Dec. 2018. <https://www.agcensus. usda.gov/Publications/2012/Online_Resources/ Census_of_Horticulture_Specialties/hortic_ 1_004_004.pdf>.

Wright, R.D. 1986. The pour-through nutrient extraction procedure. HortScience 21:227-229.

$\mathrm{Wu}, \mathrm{L}$. and L. Dodge. 2005. Landscape plant salt tolerance selection guide for recycled water irrigation. 18 Dec. 2018. <http://slosson.ucdavis. edu/Landscape_Plant_Selection_Guide_for_ Recycled_Water_Irrigation/>.

Wu, S., Y. Sun, and G. Niu. 2016. Morphological and physiological responses of nine ornamental species to saline irrigation water. HortScience 51:285-290.

Zhang, Q., K. Rue, and S. Wang. 2012. Salinity effect on seed germination and growth of two warm-season native grass species. HortScience 47:527-530.

Zhao, G.Q., B.L. Ma, and C.Z. Ren. 2007. Growth, gas exchange, chlorophyll fluorescence, and ion content of naked oat in response to salinity. Crop Sci. 47:123-131. 